\title{
Excavation of an Earth Mound, Bowie County, Texas
}

\author{
A. T. Jackson \\ Unknown
}

Follow this and additional works at: https://scholarworks.sfasu.edu/ita

Part of the American Material Culture Commons, Archaeological Anthropology Commons, Environmental Studies Commons, Other American Studies Commons, Other Arts and Humanities Commons, Other History of Art, Architecture, and Archaeology Commons, and the United States History Commons

Tell us how this article helped you.

This Article is brought to you for free and open access by the Center for Regional Heritage Research at SFA ScholarWorks. It has been accepted for inclusion in Index of Texas Archaeology: Open Access Gray Literature from the Lone Star State by an authorized editor of SFA ScholarWorks. For more information, please contact cdsscholarworks@sfasu.edu. 


\section{Excavation of an Earth Mound, Bowie County, Texas}

Creative Commons License

(c) (i) (8)

This work is licensed under a Creative Commons Attribution-NonCommercial 4.0 International License 


\title{
EXCAVATION OF AN EARTH MOUND, BOWIE COUNTY, TEXAS
}

\author{
A. T. Jackson
}

This large artificial mound is known as Site ET-30, A.J. Hatchel place [41BW3], Bowie County (Figure 1). The mound, located on what seems to be an old channel of Red River about one mile from the present stream, is part of an extensive village, perhaps related to other mound and village groups within a radius of three miles. The entire area, containing nine or more mounds, shows evidence of long-continued occupation by fairly large numbers of people. Judging from its size, and the surrounding indications of a large village, this particular mound may have been the early cultural center of the region. The mound has long been a prominent landmark, and in historic times has served as a place of refuge for livestock in periods of overflow.

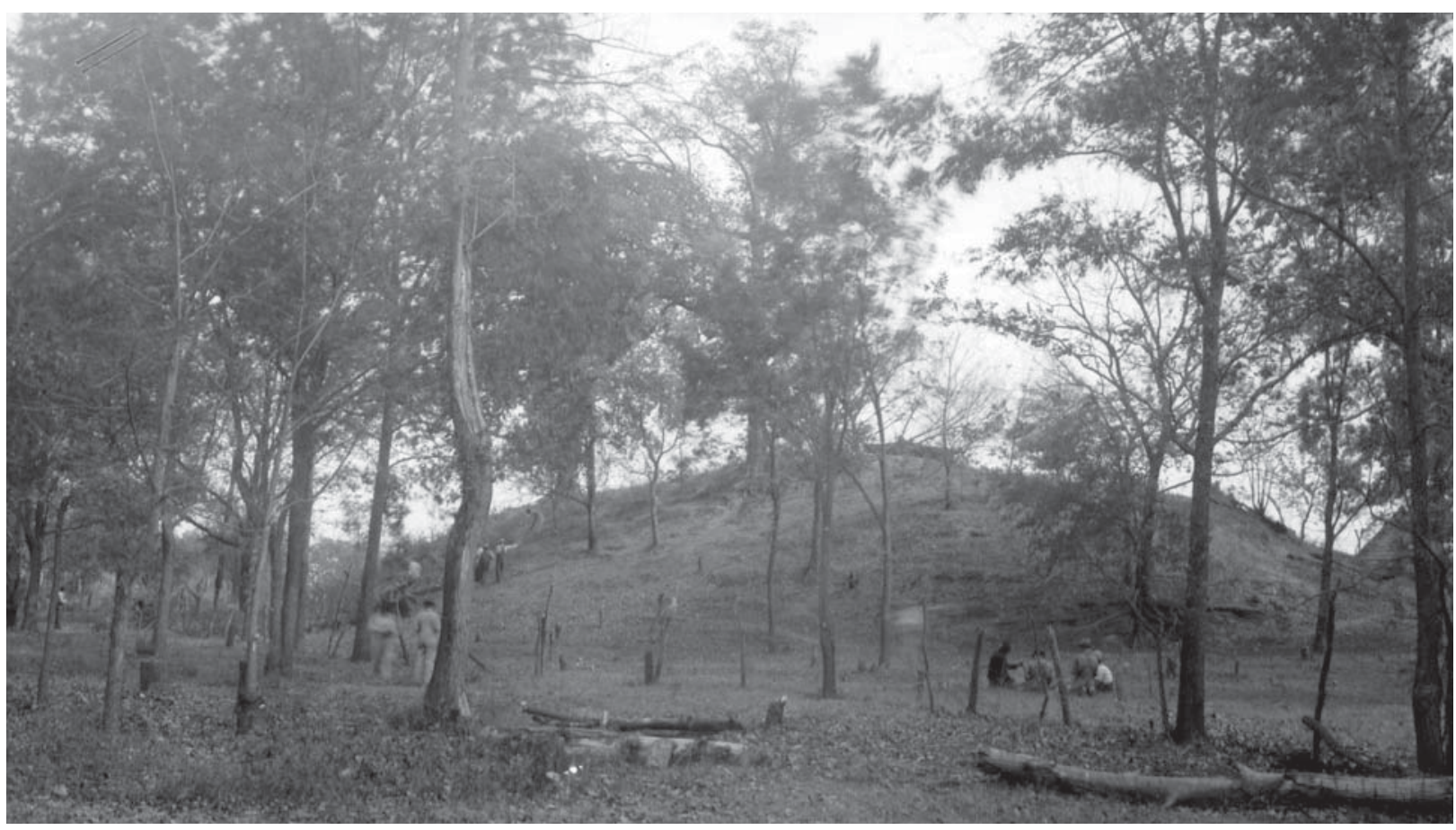

Figure 1. View of mound before after part of the timber had been cut but before staking and excavation (Courtesy of Texas Archeological Research Laboratory, The University of Texas at Austin, negative number 41BW3-9)

Clarence B. Moore, while exploring archeological sites along Red River in Arkansas in 1912, heard of the mound and navigated the Red River to that point to inspect the site. He was unable to make necessary arrangements with the landowner, and hence did no work in the mound.

\section{Brief Facts About the Excavation}

Facts pertaining to the outstanding features of the excavation will be given in very brief form. The work was made possible through a WPA-U. of T. [University of Texas] project, this unit 
of which began operations on November 1, 1938, and continued until August 25, 1939. During that time the size of the crew varied from 40 to 60 workmen. Mr. William C. Beatty, Jr. had immediate charge of the excavation. He came to us after three years' experience excavating mounds in Tennessee. At the close of this Texas excavation he resigned to continue his academic work.

The mound had a height of 30.4 feet, was 190 feet long east to west, and 145 feet wide north-south. On top of the mound grow a large burr oak tree, which had rings indicating an age of 170 years. This suggests that the mound probably had not been occupied for 200 years or more. There was no evidence of European contact.

Due to certain conditions met with, three techniques of excavation were used in the course of the work (Figure 2). First, the horizontal method was employed to secure photographs and ground plans of complete floors and house sites.

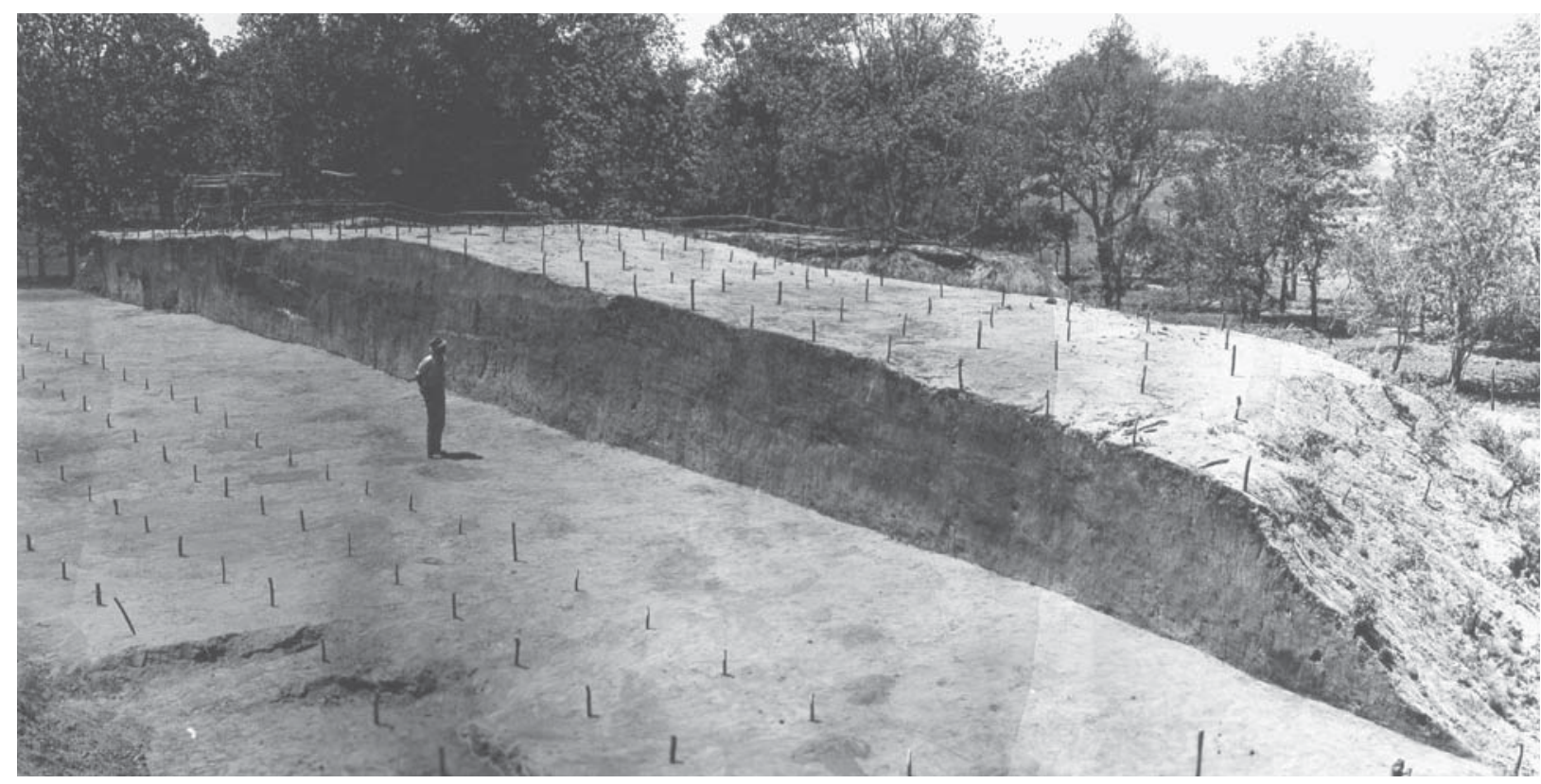

Figure 2. View showing profile of mound and two levels after excavation. Man standing on floor H. The area is staked into 5-foot squares (Courtesy of Texas Archeological Research Laboratory, The University of Texas at Austin, negative number 41BW3-207)

Next a change was made to the vertical technique. A floor was excavated to the center of the mound where notes were taken, photographs made and that half of the floor ground-planned. Lower floors then were cut to the same line to secure a taller profile. Later the remaining half was completed.

Finally, circumstances arose that made it necessary to terminate the work before the lower part of the mound was completed. Having only one month more to work, trenching was resorted to as a means of completing the profiles and securing the maximum amount of additional information. The mound was not a burial structure but a truncated pyramid of the house-mound type. Only four burials were found in the entire mound. Three of these were infants and one an intrusive adult burial.

Eight floors were found in the upper 13 feet of the mound. The presence of so many floors in a small vertical area suggests that after each period of occupation, and possible burning of the house, more soil was added and another floor prepared for building purposes. It seems very unlikely that these upper floors were built higher to guard against floods. The small vertical addition 


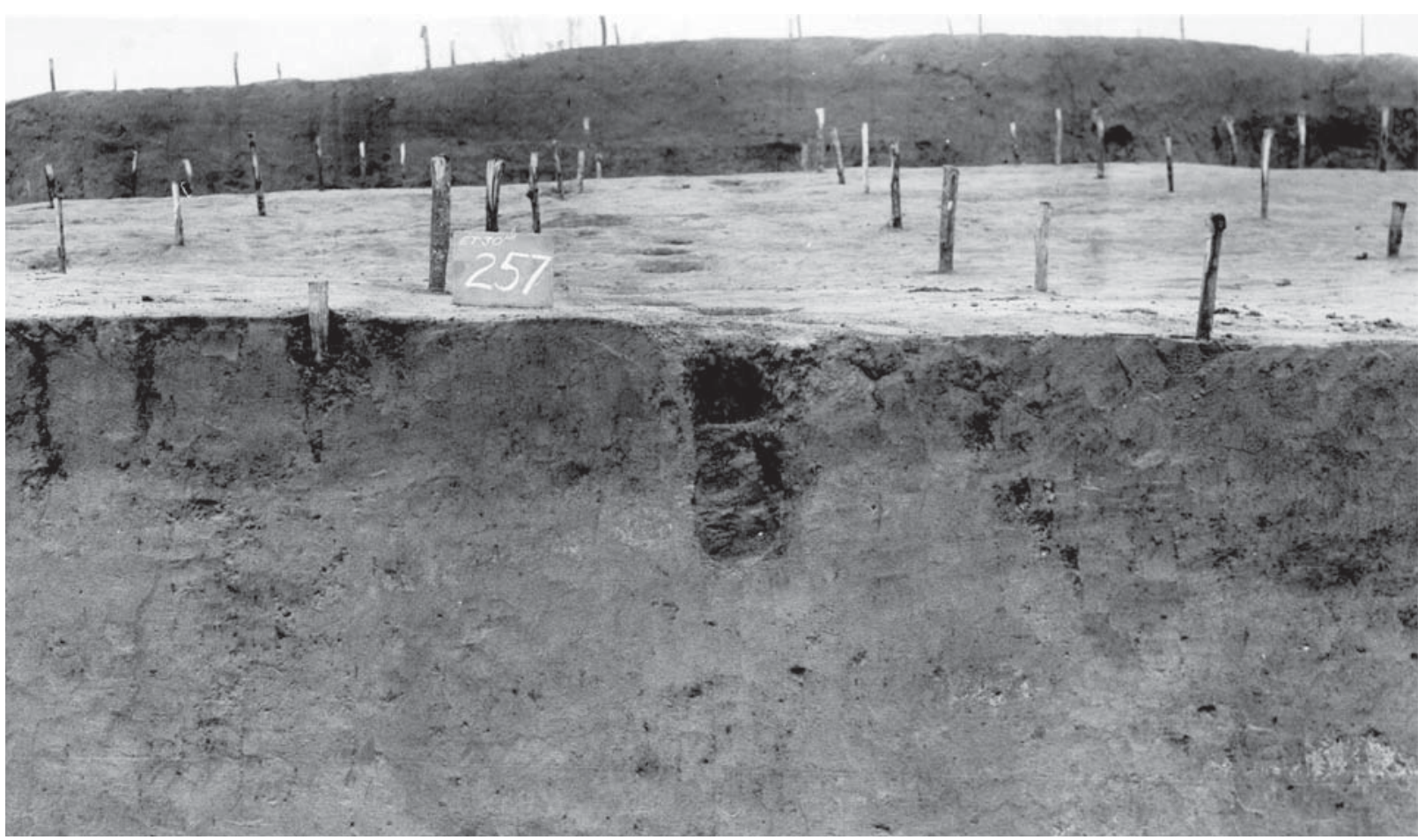

Figure 3. Posthole exposed in profile. Note the rounded bottom of the hole and the different color of the fill. Photo taken from south (Courtesy of Texas Archeological Research Laboratory, The University of Texas at Austin, negative number 41BW3-181)

resulting from a new floor could have made little difference. It is possible that after the death of a great chief or other calamity, the occupants of the village destroyed and "buried" the then existing houses on the mound.

Beneath floor "H" was a primary mound of smaller proportions, at each end of which had been fills to enlarge for the next floor, marking the beginning of the secondary mound. The primary mound seemed to have had a ramp, or slanting approach, at the south center.

Instead of including a number of closely-spaced floors, the lower portion of the mound consisted of two different structural stages. Most of the lower levels were almost sterile, as compared with the many evidences of material culture found on the upper floors.

It was found that the original mound was erected on a portion of the large, comparatively level village site and not on a natural elevation.

\section{Burials}

The first burial in the mound was on floor "E." It was not intrusive from the floor above, as shown by lack of grave outline on that floor, but was resting exactly on floor "E," apparently having been covered with the floor "fill." With the burial were a small incised vessel and one shell bead.

In the northeastern part of the mound, directly on floor " $F$ " was the grave of an infant buried on it's back in an extended position. Associated with the burial were two bowls, a water bottle, and a mussel shell "spoon." The bottle was east of the skull, and the shell artifact was inside a large black bowl. 
The third infant burial was in a pit that showed plainly on the floor " $\mathrm{H}$ " surface. The skull was slightly more than a foot beneath the floor. The skeleton was in an extended position, on the back, with the head to the north. The grave contained three pottery vessels and a mussel shell. The shell was east of the left elbow.

The fourth, and last, burial was that of an adult, apparently intruded into the western edge of the mound above the old village floor. The skeleton, in a good state of preservation, was extended on the back, with three small pottery vessels between the knees. This intrusive burial seems to be more recent than any of the others.

An interesting detail in connection with the grave goods from the mound burials is that the vessels accompanying the infants were large enough to have been used for utility purposes, while those with the adult might be classed as "toys."

\section{House sites}

Each floor contained from one to three house sites, outlined by postholes (Figure 3). Of the twenty houses, 15 were roughly circular (Figure 4) and five irregular in shape. They range in size from 10 to 49 feet, with an average diameter of about 30 feet. A number of the houses had protruding roofed entranceways three to four feet wide and about five feet long, as indicated by postholes (Figure 5). Of 14 definite outside entranceways, $57 \%$ were to the southeast, $22 \%$ to the south, $14 \%$ to the east and $7 \%$ to the northwest. Wattle, apparently from burned clay roofs, was present in four of the houses. There was no evidence of a large central supporting post in any case.

Seven houses contained fire pits, while three others had deposits of ashes without definite pits. Most of the fire pits were near the center of the houses. Eight houses had storage pits (Figure 6), some with two or three such pits containing rubbish.

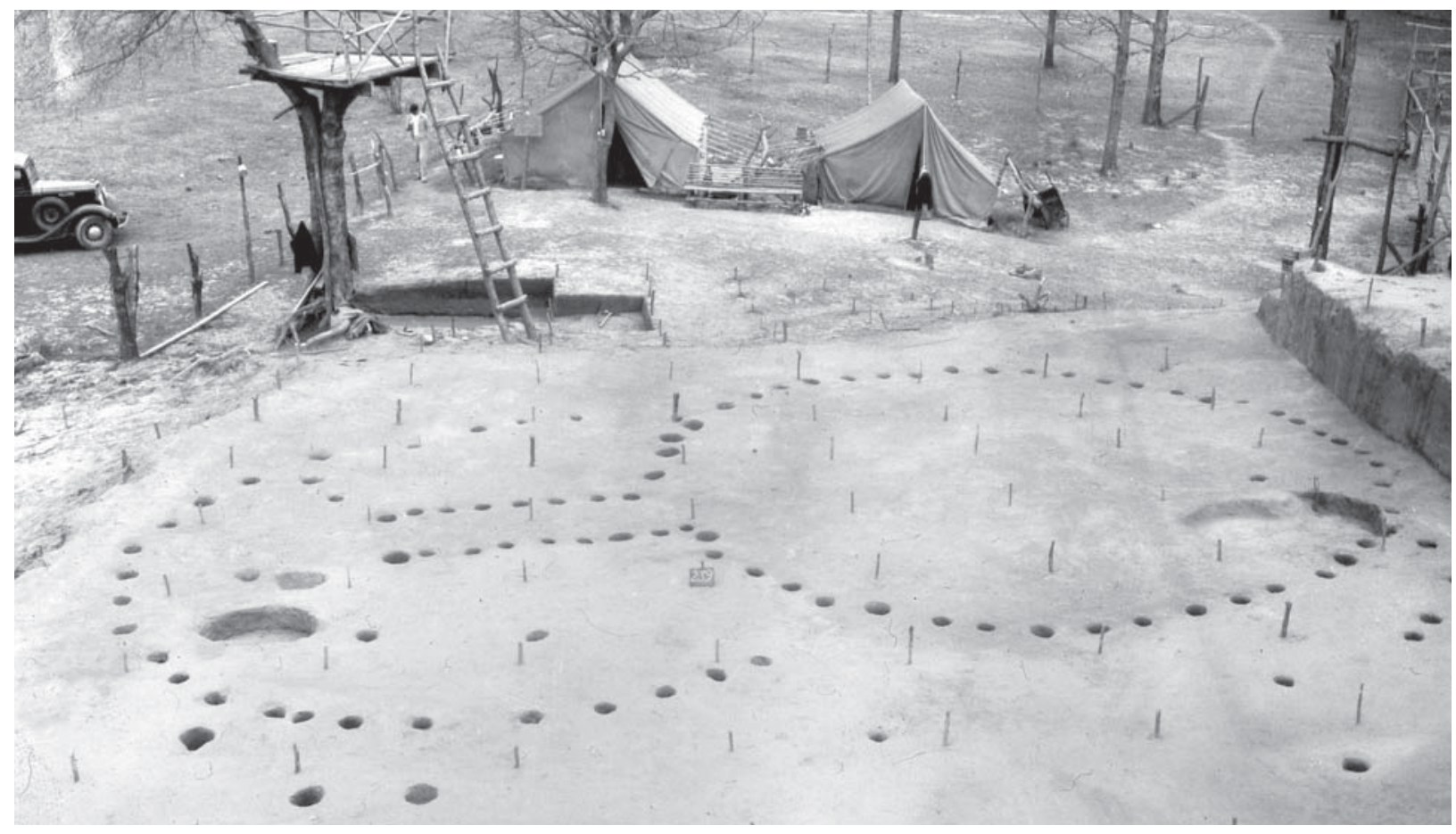

Figure 4. House sites (features 16 and 17) superimposed on phase "H" floor (Courtesy of Texas Archeological Research Laboratory, The University of Texas at Austin, negative number 41BW3-163) 


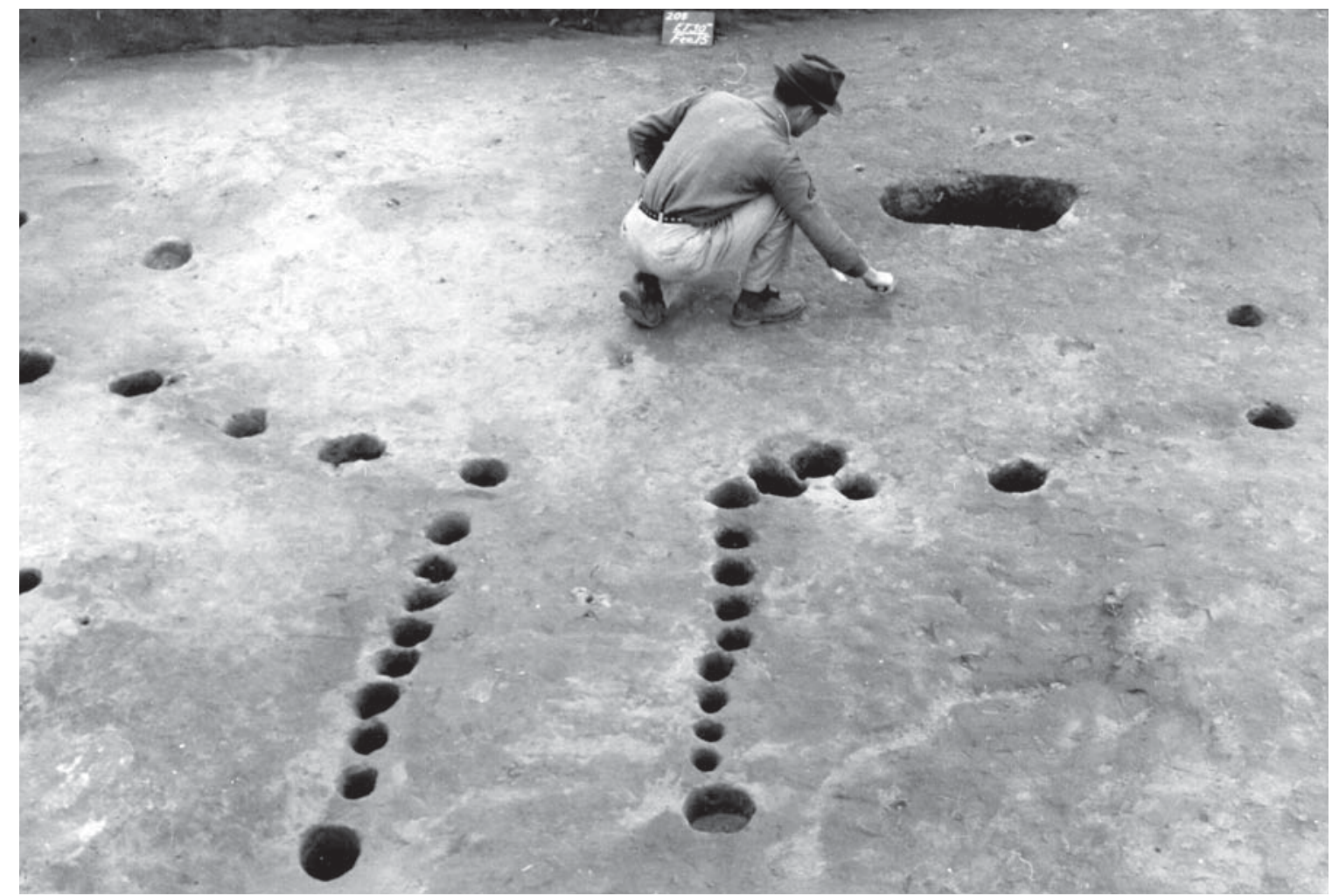

Figure 5. Another view of southern half of Feature 15 with workman troweling near center (Courtesy of Texas Archeological Research Laboratory, The University of Texas at Austin, negative number 41BW3-128)

Floor "A" contained a house at the east and west ends, [and] a large storage pit in the northwest corner. Between the two houses was a "compound-like" area that may have contained drying racks or lean-to shelters, as shown by postholes.

Floor "B" had at its western end a house site 25 x 50 feet. In the center of the floor was a small house 10 feet in diameter, and at the east end was one 30 feet in diameter.

At the west end of the floor "C" was the outline of a structure 30 feet in diameter. The house remains consisted of a large section of wattle over the entranceway, a fallen roof beam and a large fire pit. A small elevation at the east end of the floor was surrounded with postholes. Two storage pits were near the center of the floor.

On floor " $D$ " the postholes were grouped in the east and central sections. The holes suggest various superimposed structures.

Floor "E" had a large house in the center with several storage pits and ash deposits. At the west end of the floor was a circular posthole outline, enclosing three refuse pits.

Near the center of floor "F" was a house with an almost perfect entranceway to the south. The entranceway consisted of 17 wall aligned holes, some of which contained the remains of cedar posts (Figure 7).

At the northeast corner of floor "G" were 11 postholes arranged around a central fire pit. This may have been the remains of a roughly square structure (Figure 8). At the north-central part of the floor were two or more superimposed houses; or perhaps one structure with double walls 
and many side braces. There were 127 postholes in this feature.

Floor " $\mathrm{H}$ " contained three definite structures and remains of perhaps two others. To the southwest were two superimposed structures; in the center was another house with several postholes containing wood or charcoal. In the northeast section were remains of two or more circular house sites.

At the west end of, and beneath, the mound on the old village level was a large circular house site, divided by a partition into two "rooms" (Figure 9).

\section{Material Culture}

Aside from the grave goods and many scattered potsherds, the material culture was scantly represented in the mound. The projectile points, mostly small, were of the stemmed and unstemmed varieties; the former had expanded and contracted bases, the latter had straight and concave bases. A cache of 16 small triangular points lay in a pile.

Many fragmentary pipes were found, as well as an occasional broken vessel. Two unusually large polished stone celts (Figure 10) lay

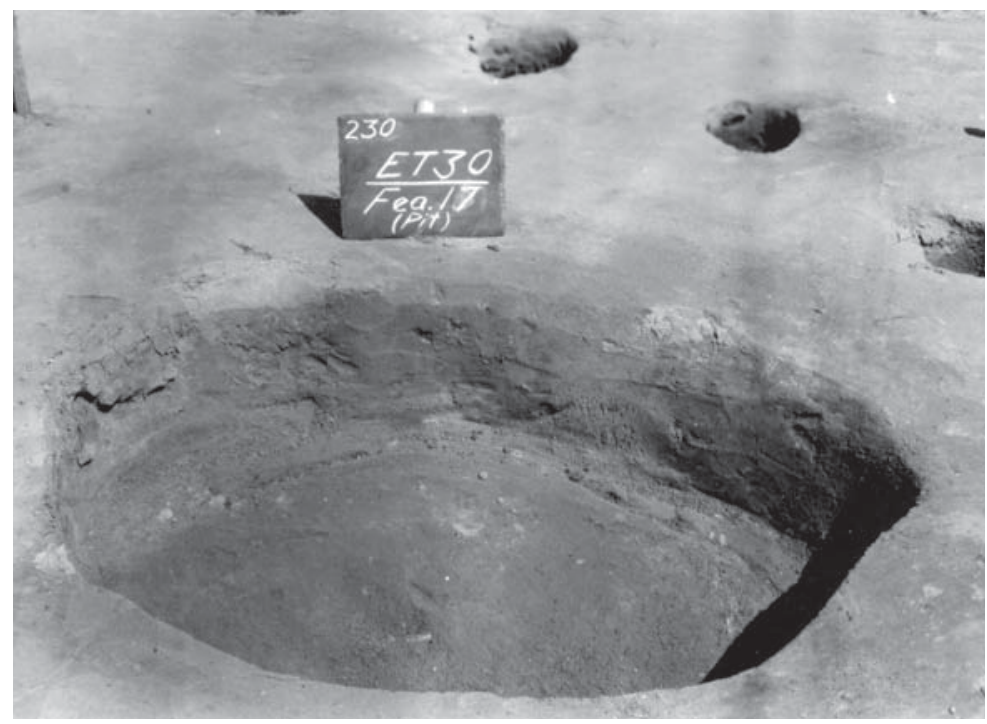

Figure 6. Storage pit in house site, Feature 17. Taken from west (Courtesy of Texas Archeological Research Laboratory, The University of Texas at Austin, negative number 41BW3-154)

on the floor very near together. Among the ornaments were bear tooth pendants and a turquoise bead.

\section{Stories Gleaned From Facts}

A number of interesting details regarding the probable everyday life of the people may be gleaned from the findings. For example, at the west end of the mound on floors "A," "B" and "C" was a deposit of almost sterile humic soil that showed considerable evidence of decayed plant matter. The soil was a deep, rich black and may have been used for growing a small patch of corn or vegetables on the mound.

The shard distribution on floor " $H$ " showed that the areas of concentrated pot fragments were between and to the rear of the houses. This suggests much outdoor activity and that broken vessels may have

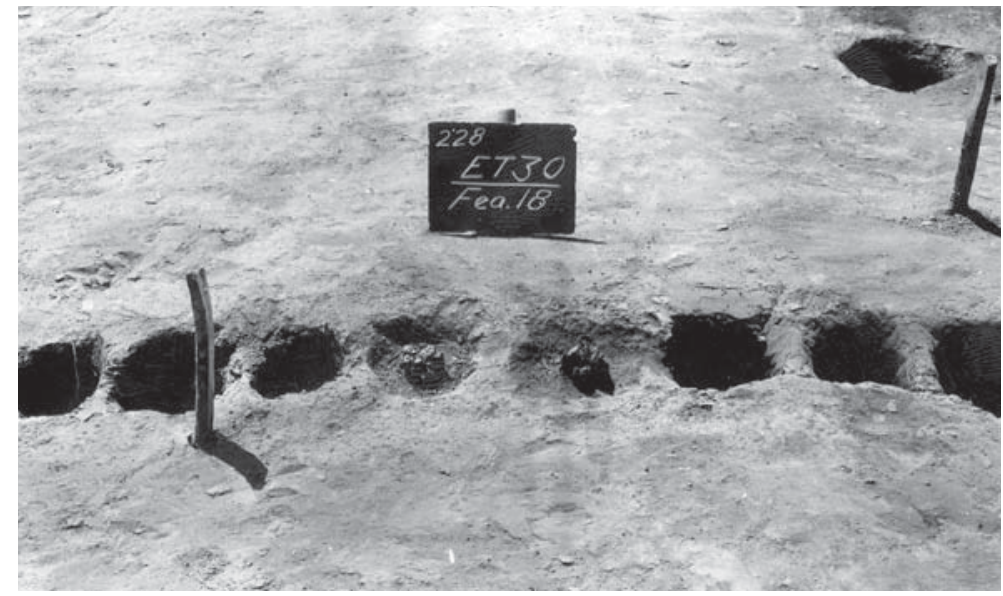

Figure 7. Part of entranceway showing wood in postholes. Charred wood, remains of posts, apparently cedar. Feature 18 (Courtesy of Texas Archeological Research Laboratory, The University of Texas at Austin, negative number 41BW3-152). 


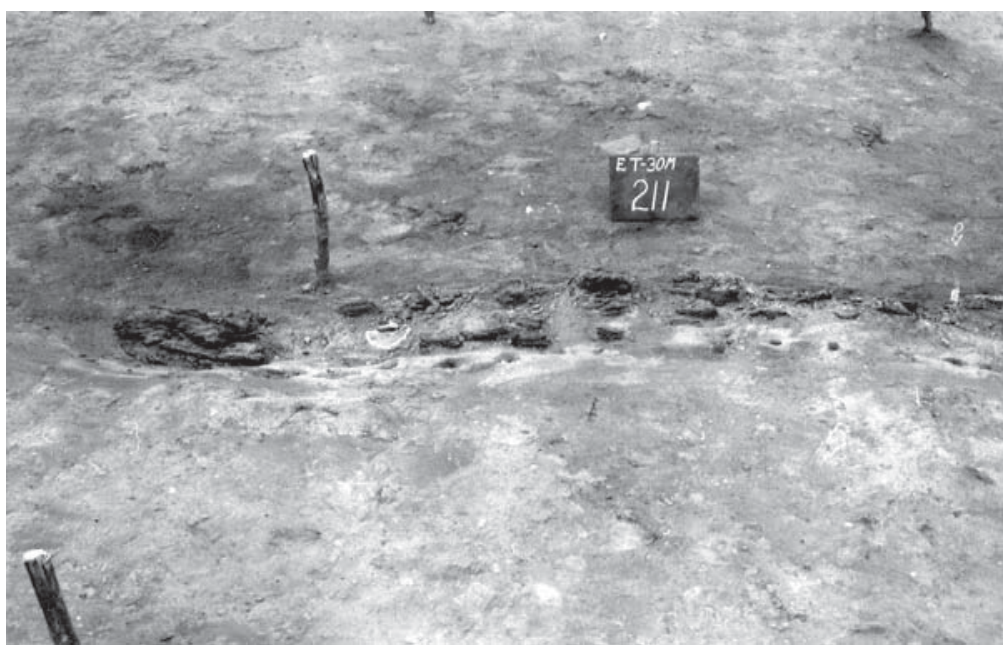

Figure 8. Remains of cedar log on phase "G" floor (Courtesy of Texas Archeological Research Laboratory, The University of Texas at Austin, negative number 41BW3-134) been thrown out to the sides and rear of the houses, thereby leaving the south side — or main approachmore or less clear of rubbish.

Various bits of evidence indicate the existence of the caste system. In addition to the seemingly significant practice of burying in the mound infants of importance, other facts suggest that this large mound may have been the abode of ranking chiefs and their families. This theory as to the possible use of the mound agrees in general with the accounts of certain early explorers. There also remains the possibility of the mound having been the location of the "town house" or so-called temple.

An attempt to work out a step-by-step development of the large mound suggests the division of its growth into five periods. The first represents the occupation of the original village, that later was covered by the mound. This is floor "K."

The second period comprises structures "J" and "I" and might be called the period of "temple" mounds. Structure "J" may have been merely a clay base for the next higher addition.

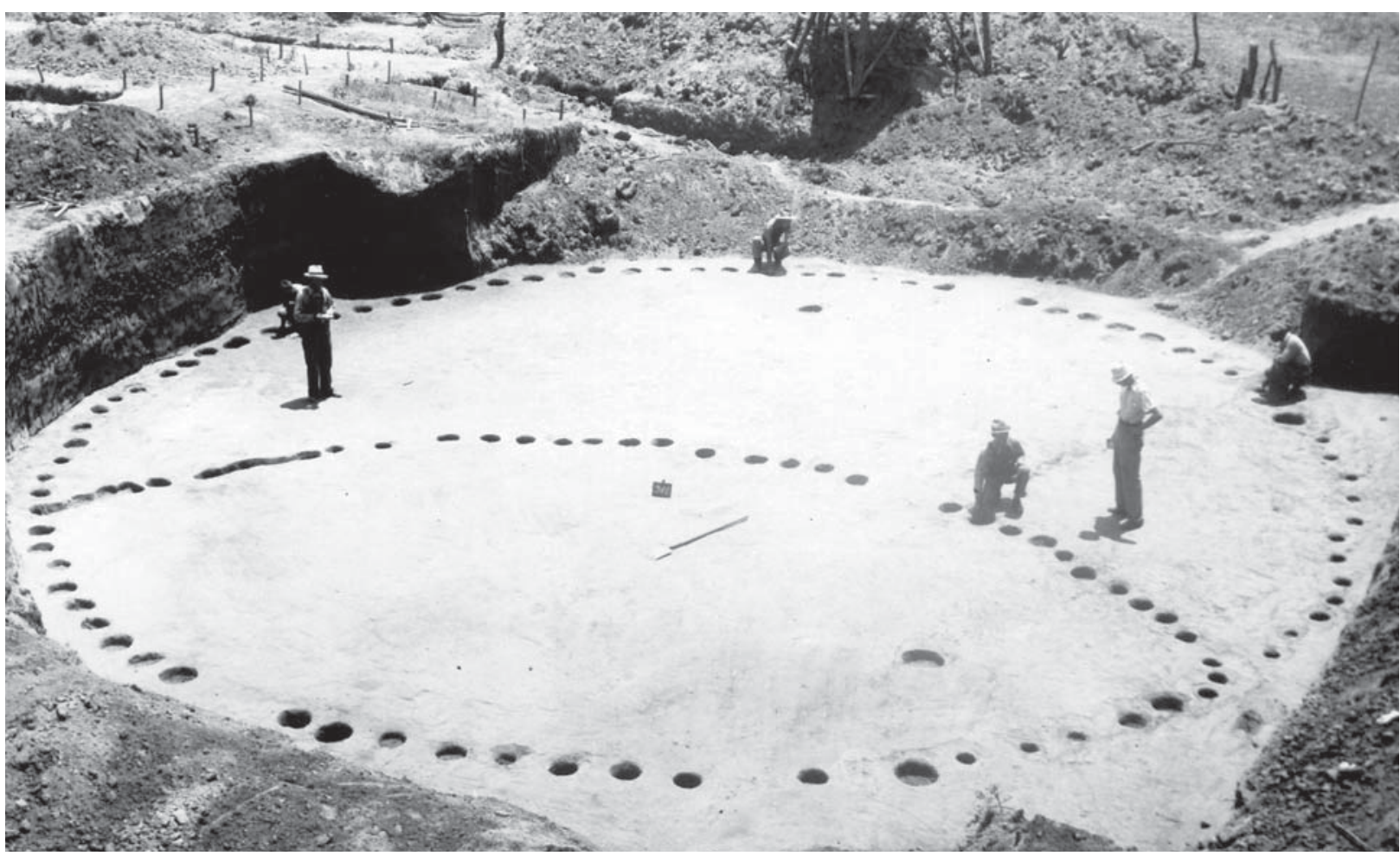

Figure 9. Feature 25, men working. Shovel blade points north (Courtesy of Texas Archeological Research Laboratory, The University of Texas at Austin, negative number 41BW3-265) 


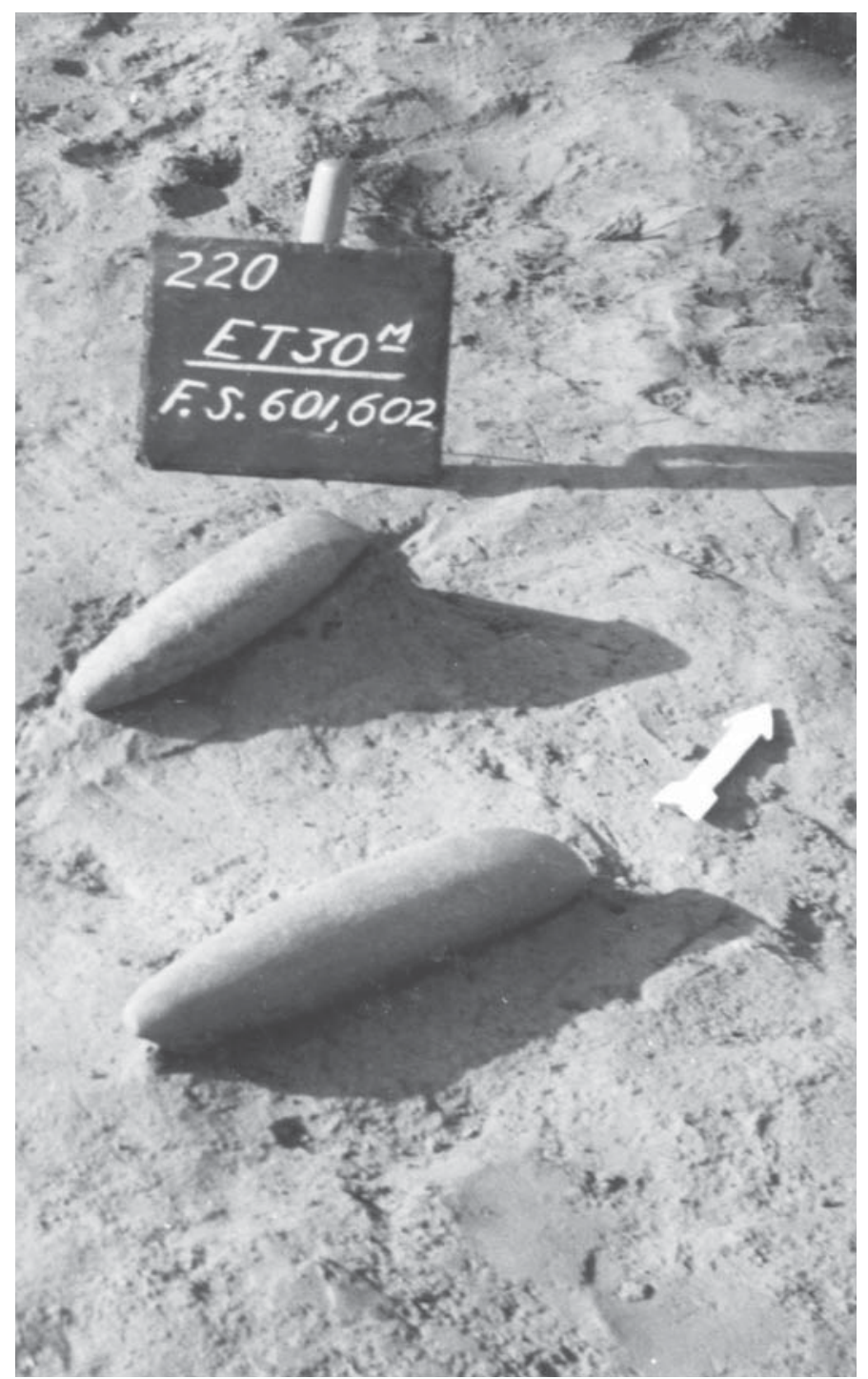

Figure 10. Large stone celts in place at mound (Courtesy of Texas Archeological Research Laboratory, The University of Texas at Austin, negative number 41BW3-143)
The third period, representing end additions to the mound and the erection of floors "H," "G," "F," "E," and "D" may be called the period of large occupational levels. It possibly shows extreme dominance of the ruling classes.

The fourth is the period of smaller occupational levels, and includes floors "C," "B," and "A" - the last additions to the mound.

The final period, since abandonment by the Indians, shows the results of greater floods, erosion and heavy wind deposit. The mound has accumulated around its edges a protective soil covering, somewhat enlarging its base.

\section{Laboratory Study of Materials}

More than 20 usable dendrochronology specimens were recovered from the mound, and will be made available to tree-ring experts working on the problem of a "calendar" for the Mississippi Valley.

Our San Antonio laboratory is now making an intensive study of other returns from this mound, and from the adjacent village and cemetery. The work is not sufficiently near completion to hazard any definite conclusions. But we are hopeful of working out, from the thousands of potsherds found on the various floors, a pottery chronology that may be helpful in East Texas, Louisiana, Arkansas and Oklahoma.

If there is a "Caddo-root" in the Southwest, possibly our findings also may be of interest to that region.

\section{Notes}

Paper presented at the 1939 Texas Archeological and Paleontological Society meetings in Abilene, Texas. Printed with the premission of the Texas Archeolgical Research Laboratory. Origional on file at the Texas Archeological Research Laboratory, The University of Texas at Austin, 41BW3 File. 